\title{
Article \\ On the Roots of Media Ecology: A Micro-History and Philosophical Clarification
}

\author{
Corey Anton \\ School of Communications, Grand Valley State University, 210 LSH, 1 Campus Drive, Allendale, \\ MI 49401-9403, USA; antonc@gvsu.edu; Tel.: +1-616-331-3321 \\ Academic Editor: Robert K. Logan \\ Received: 19 May 2016; Accepted: 10 June 2016; Published: 4 July 2016
}

\begin{abstract}
This paper provides a brief review of media ecology. It is partly a micro-history of the tradition, and partly a philosophical clarification of how and why "systems-theory orientations," literacy studies, and the rapid spread of new media were all essential to its germination, growth, and proliferation. Finally, the paper offers concluding remarks regarding social constructionist thought and how it relates to the media ecology tradition.
\end{abstract}

Keywords: media ecology; Marshall McLuhan; Jack Goody; systems-theory; literacy studies; new media; social construction

\section{Introduction}

To explore the ancestry line of media ecology, we first need to touch upon media ecology today, and then, after considering its current composition, we can identify its roots as well as the soil and overall atmosphere in which it sprouted and developed. This implies that we must differentiate between a history of media ecology as a field of study and a history of the ideas and thinkers that precipitated and nourished the emergence of the media ecology tradition in North America. The following, therefore, is partly a micro-history of the tradition and partly a philosophical clarification of how and why "systems-theory orientations", literacy studies, and the rapid spread of new media were all essential to its germination, growth, and proliferation. Finally, a concluding remark addresses how social constructionist ideas relate to the media ecology tradition.

The particular expression, "media ecology", grew out of a conversation in 1967 between Neil Postman, Marshall McLuhan and Eric McLuhan [1,2], and, within a year, Postman was using it in public talks. By 1971, New York University (NYU), Postman's home institution, had established a doctoral program by that name, and then, in 1998, NYU, The Toronto School of Media Studies, and St. Louis University joined resources to form the Media Ecology Association (MEA). Within four years of its establishment, the MEA launched an international journal, Explorations in Media Ecology, and, today, several books series are devoted to media ecology.

For many scholars, especially members of the MEA, media ecology refers to the study of media as environments and environments as media [1-3]. It focuses upon dominant communication technologies to account for both cross-cultural conflict as well as for the distinguishing characteristics of a given culture and/or historical period. Although media ecological thinking can be found back in the ancient world (e.g., admonishments against making "graven images", or in Plato's Phaedrus, where Socrates warns about the effects writing will have on memory and people's sense of wisdom), it was not until the 20th century that media ecological thought became more prevalent within popular sensibilities. Today, in the ultramodern 21st century, media ecological orientations are pervasive, mainly because communication technologies have altered countless patterns of interaction before people's very eyes: many people have witnessed cell phones change the nature of social interaction, video technologies alter notions of privacy, and robotic automation change the nature and meaning of employment. Hence, 
spanning and integrating ancient, modern and postmodern world-views, media ecology examines cultures and personhood as intricately intertwined with dominant communication technologies.

Three roots serve as the main nutrient sources to the media ecology tradition: Marshall McLuhan, Walter J. Ong, and Neil Postman [1-3]. These three-McLuhan arguably at the center-constitute a core, with a number of scholars branching out from that core. So, for example, thinkers such as Harold Innis, Lewis Mumford, Eric Havelock, Jack Goody, Susanne Langer, Edmund Carpenter, Elizabeth Eisenstein, Jacques Ellul occupy a major inner layer of branches, and then thinkers such as Ludwig Bertalanffy, Alfred Korzybski, Kenneth Boulding, Erving Goffman, Edward Hall, Dorothy Lee, Daniel Boorstin, Gregory Bateson, Paul Watzlawick, Tony Swartz, Susan Sontag, Denise Schmandt-Besserat, James Carey, David Olson, Leonard Shlain, Pierre Teilhard de Chardin, and Julian Jaynes occupy a further layer. There are also a number of contemporary scholars in the MEA who have produced books, manuscripts, and who remain active in the organization. This includes but is not limited to: Lance Strate, Thom Gencarelli, Janet Sternberg, Paul Levinson, Paul Soukup, Susan Barnes, Casey Lum, Paul Grosswiler, Sara van den Berg, Robert K. Logan, Brett Lunceford, Fernando Gutiérrez, Sheila Nayar, Ellen Rose, Brian Cogan, Phil Rose, Edward Tywoniak, Peter K. Fallon, Alex Kuskis, Steven Reagles, Valerie V. Peterson, Peter Zhang, Eric Jenkins, Robert MacDougall, and myself. And, finally, there are also many thinkers who contemporary media ecologists have enlisted as within the bounds of media ecology, scholars such as Elias Canetti, Georg Simmel, J.J. Gibson, René Girard, and Guy Debord among others.

\section{The Larger Environment}

Now that a few remarks have been made about media ecology today, we are ready to explore the soil and atmosphere in which the seedling took root. Media ecology, as may be evident from the scholars listed above, is not reducible to a single tradition or particular line of scholarship or even to a single discipline. Joshua Meyrowitz suggests that the specific, substantiating research lines of media ecology "have developed out of distinct disciplines (the classics, psychiatry, English, religion, anthropology, history, etc.)," and, accordingly, these works are not "generally conceived of as being parts of one body of literature" [4] (p. 22). Nevertheless, one complex multidisciplinary body of literature is exactly what media ecology has become.

As far back as the 1960's, Postman sought to express how multiple sources of thought were growing together, intertwining if only underground. He, along with Charles Weingartner, used the expression: "the Sapir-Whorf-Korzybski-Ames-Einstein-Heisenberg-Wittgenstein-McLuhan-et al. Hypothesis" [5] (p. 101). The motive behind this unwieldy agglutination-the expression that grew into "media ecology" - was to suggest that individuals across many different fields had come to some remarkably similar (or at least highly resonant) insights regarding humanity, perception, cultural evolution, and the constitution of social/psychological order. It also stressed the primacy of "relations" over "things" and pointed to mediation as a dynamic mode of connectivity. Postman and Weingartner promoted what Dewey and Bentley, in Knowing and the Known, called "trans-action" in distinction to mere "inter-action." More precisely differentiated, Dewey and Bentley write:

Inter-action: where thing is balanced against thing in causal interconnection. Trans-action: where systems of description and naming are employed to deal with aspects and phases of action, without final attribution to "elements" or other presumptively detachable or independent "entities", "essences", or "realities", and without isolation of presumptively detachable "relations" from such detachable "elements." [6] (p. 108).

Increasing numbers of scholars were growing more and more suspicious of a detached observer, of assumptions regarding value-free language, of belief in a world complete unto itself to which persons and/or their material conditions could be added without any impact or effect. Postman and Weingartner sought accounts aligned with the idea that the "observer" cannot be separated from the "observed", especially where matters of technological mediation are concerned [5]. 
One of media ecology's main assumptions is that we can best understand technological mediation and the evolution (e.g., the socio-historical/material constitution) of human consciousness and culture through a systems-view. In 1974, Lee Thayer, a multidisciplinary systems theorist, established the journal titled Communication, with an astonishing editorial board that included not only Marshall McLuhan and Walter Ong, but such notable scholars as: Herbert Blumer, Daniel Boorstin, Kenneth Boulding, Kenneth Burke, George Gerbner, Harold Lasswell, Claude Levi-Strauss, Floyd Matson, F. S.C. Northrop, Ithiel de Sola Pool, Karl Pribram, Anatol Rapoport, David Riesman, Jurgen Ruesch, Wilber Schramm, Harley Shands, and Geoffery Vickers. As one of the intellectual predecessors to the MEA's current journal Explorations in Media Ecology, Communication brought together scholars from many different fields, areas such as psychology, sociology, physics, biology, engineering, mathematics, economics, etc. All were realizing how their fields of study and bodies of knowledge were caught within language practices and communication technologies more generally.

The 1960's and 70's witnessed a flood of scholarly reflection upon communication and symbolic processes not only because many fields were discovering how their objects of investigation were mediated, but also because of the rise of the telecommunication industries. Television, in particular, was central to burgeoning interest in media studies across North America. As TV sets entered people's homes, they poured out social unrest: concerns over gender and racial inequality, political strife, rapid shifts in values, and varieties of global conflict [4,7].

But other important elements in the soil need to be mentioned. In particular, the 20th century not only witnessed the first large scale attempt at universal mass education, it watched the project buckle under the weight of television and other electronic media. By the end of the century many people were concerned over growing illiteracy rates. Moreover, many scholars had become much more sophisticated in their inquires into the character and nature of alphabetic literacy. The year 1963 is marked by some scholars as a pivotal year for media ecological research [8]. Within a span of a little over twelve months, McLuhan's The Gutenberg Galaxy [9], Havelock's Preface to Plato [10], Goody and Watt's "Consequences of Literacy" [11], and Levi-Strauss's The Savage Mind [12] all were first published. These texts provocatively identify significant changes in the nature of the spoken word and in the nature of communicative practices with the advent of literacy; they pointed to the important role literacy had played in making the modern Western world.

Two other notable contributions were David Olson's The World on Paper [13] and Jack Goody's The Interface between the Written and the Oral [14]. Both masterfully address some of the more salient research lines on literacy at the roots of media ecology [13-18]. One line came out of psychology and concerned scholars such as Vygotsky, who claimed that certain mental abilities were dependent upon literacy, almost as if literacy single-handedly transforms basic intellectual operations. Along similar lines, Alexander Luria tested illiterate peasants to illustrate their apparent inability (or at least unwillingness) to think with abstract categories and/or to accept syllogistic reasoning [9]. Another line of contributions came from anthropology, especially turn of the century thinkers such as Sir James George Frazer, with his massive The Golden Bough [19] as well as Lucien Levi-Bruhl's highly influential The Notebooks on Primitive Mentality [20]. These two popular and widely read anthropologists significantly influenced subsequent thinking regarding the differences between "savages" and "civilized" human beings. Sylvia Scribner and Michael Cole, in their book The Psychology of Literacy camped all of the aforementioned thinkers together, basically accused them of something akin to technological determinism, and then set out to experimentally test the claim that literacy alters human consciousness and turns "savages" into "civilized human beings" [21]. Through a series of studies, they substantially refuted any claim to a great divide between oral and literate mind and sought to show, more modestly, the possibility of changes in skills but not general abilities. Along the way, however, they misunderstood and misrepresented the view that Goody, in particular, was espousing, and this returns us to the original point of departure about bringing systems-theory to the evolution (and socio-historical/material constitution) of human consciousness and culture. 
An essential part of the task, as Goody identifies it, is to overcome the deeply entrenched kinds of "mentalism" in contemporary psychology [14]. That is, contemporary experimental psychology often traffics in the distinction between "abilities" and "skills" and therein reifies an "ahistorical", "acultural" mentalist sort of subject. This can be witnessed when Scribner and Cole try to test for something like abstract logical abilities as they could be produced by literacy. For Goody, in contrast, the main point is: what kinds of thought can people have-both in the short term and in the long term-because of pen and paper? In some ways, Goody was addressing what decades later would be called, "embodied cognition." The point is that the contemporary psychological distinction between "abilities" and "skills" is highly problematic. There's no such thing as "abilities" or "skills" in the abstract, that is, without the particular context and material conditions for the exercise of those abilities/skills. When we change our methods and means of communication we're actually changing the material conditions in which any skill or ability would develop or have influence. Goody employs the term "capacities" to undercut the ability/skill differentiation. I quote Goody at length:

... I myself could not, do not, remember the telephone number of my own office. That does not stop me from calling my colleagues because I look the number up in my telephone book, store it in my short-term memory, then dial. Now that I have a new type of telephone with its own memory I don't even need to look it up. My memory skills are not engaged. Yet I have a capacity to talk to vast numbers of people on this earth at short notice.

To expect that this capacity would show up on a series of tests suffers from three theoretical difficulties. It assumes, first, that such capacities can be described, or better described, at a higher level of generality. Secondly, that this higher level of generality shows up in the "higher" mental processes. Thirdly, that these higher mental processes go on inside the mind alone. This last sentence sounds like a tautology. But if one defines skills and knowledge as "mental" in the sense that they are entirely contained within the mind, and have to be so tested, you quickly reach a point of no entry into the study of human interaction ... We are touching here upon the external-internal problem that has dogged so much thinking, in psychology, philosophy, and elsewhere ... Norbert Weiner asked his readers to imagine a mechanic with an artificial arm trying to repair an engine. Is the arm part of the machinery with which he is struggling, or part of the mechanic who is working on the engine? ... When a map or book intervene between the object and subject we are dealing with 'mind' out there as well as with mind inside ... writing presents us with an instrument capable of transforming our intellectual operations from the inside; it is not simply a question of a skill in the limiting sense but a change of capacity. The capacity depends upon interaction between individual and the objects mediated by writing, and so cannot in many cases be mocked-up in ways that would test general abilities (for example, of abstract reasoning and memory) ... [14] (pp. 253-256).

Scholars can continue to raise questions about what effects a technology has upon a person's general "abilities" or inner "mental" constructs, but they need not do so. On the contrary, they might chose to carefully document how individuals and/or whole cultures have been capacitated to function with technologies as extensions and as environments [13].

McLuhan's well-known response to General Sarnoff's claims regarding media effects cut directly to this point [7]. Sarnoff, talking about the relationship between technologies and their consequences, suggested, "The products of modern science are not in themselves good or bad; it is the way they are used that determines their value," to which McLuhan critically responded, "That is the voice of the current somnambulism ... It has never occurred to General Sarnoff that any technology could do anything but add itself on to what we already are" [7] (p. 23).

Media ecology grew, then, on one front, from a desire to show how print based literacy was blinding people to simultaneous interconnections and, on another front, from the nutrient soil provided by the electric age. Only as electric technologies began to be pervasive could the systematic 
complexity of social and psychological relations afforded by print be revealed. Atomistic, linear, and compartmentalized thought was the natural outcome of print, the symptom, as it were, of literate sensibilities. The abstract proclivity to separate "content" from "form" and the tendency to isolate items into a "one-thing-at-a-time" sequence of causal relations were products of literacy and obstacles to apprehending the dynamic nature of technological mediation.

Something should be said in this context about McLuhan's use of "formal cause". A key principle informing McLuhan's thought, one that only recently has come to adequate attention, was McLuhan's attunement to formal causality [22-24]. Aristotle distinguished four kinds of causality: material, efficient, formal, and final. For example, consider a spoon. It needs to be made of some material (steel, wood, plastic, etc.), and the materials must be fashioned in a particular sequence or process by the maker. In addition to these material and efficient causes, there are formal and final causes. The formal cause of the spoon is what the maker had in mind in setting out to produce the spoon. It is the idea guiding processes and expectations, thus enabling anyone to recognize the spoon "as" a spoon. Formal cause, therefore, enables the maker to know when the fashioning of the spoon is completed, when other people can clearly see "what it is". The final cause of the spoon is its "for-the-sake-of-which", the reason we wish to have the spoon, the end served by the spoon: a particular kind of eating. McLuhan appreciated how any environment or technology, as formal cause, grows an appetite, an orientating capacity, a set of sensibilities that seek satisfaction elsewhere. Formal cause is not only the source of "rear-view mirror" thinking (seeing the present through the past; e.g., "horseless carriage"), it is also what gives media forms the "Midas touch", the sense that anything touched by a media form gets made over in its image [7]. For example, print, as formal cause, had groomed people for uniformity, seriality, standardization, and lineal "one-thing-at-a-time" reasoning in countless areas of their lives, and, so too, the electric age was the formal cause of ground-awareness, attention to simultaneity, and interest in "relations" and "systems" rather than in "things" and their "properties".

Consider the NRA's slogan, "Guns don't kill people, people do" [2,7]. Such analytic compartmentalization typifies the need for a more robust systems-view of gun violence. Lance Strate, in his elucidation of the media ecology traditions, suggests, "If you disagree with this argument, and believe that there is greater potential for violence with firearms than without them, then you believe that the medium is the message" [2] (p. 130). Not only are there, annually, hundreds of accidental gun deaths in the US, but only the most literal-minded person could believe that anyone thinks "guns," in and of themselves, kill people. No one imagines that a gun somehow manufactures itself, fills itself with ammunition, hops off of a gun rack and starts shooting. The bogus separation of guns from people is already the literate dis-orientation, the non-systems view. Guns are extensions of people, and people who have extended themselves with guns kill more people than people who do not have such extensions. The systems-view informing the media ecological tradition would encourage people to understand how a technology does not merely get added to an environment; it changes everything. Paul Levinson nicely captures this issue where he writes that "The addition of a drop of blue dye to a glass of water results not in blue dye plus water, but in blue water: a new reality," as cited in [25] (p. 35).

\section{Final Remarks}

Before closing, one final observation should be made regarding the growth and proliferation of social constructionist thought, a neo-Marxist view that enlivened long-standing concern over the difference and/or relationship between "nature" and "nurture".

Social constructionist thought is mentioned only because it alludes to the rocky soil and arid conditions that motivated some scholars to seek the greener pastures of the media ecological tradition. Many who went to college in the 1980 and graduate school in the 1990s remember how popular social constructionist ideas were [26]. It was hard to go anywhere and not hear something (anything and everything) being described as "socially constructed". As a response, some scholars sought to more rigorously document the phenomenological constitution underlying social construction [27]. 
Phenomenological focus upon the body, especially the difference between the senses, offered a needed corrective to many social constructionist positions, but even a phenomenologically-informed social constructionist view seemed, all said, pretty lacking in historical depth and breadth [28-30].

Media ecology, more than any other tradition, provides a more robust manifestation of what so many social constructionist scholars had been seeking. We might call it, "socio-historical constructionism with teeth." Clearly, it is one thing to sweepingly proclaim that people socially construct "reality" or to vaguely suggest that "gender" or "race" or "self" or "intelligence" or "science" is socially constructed. It is quite a different matter to engage the socio-historical material technological conditions - the total human environment - which built the cultures and selves we now experience and take-for-granted. To explore the nature of alphabetic literacy, to learn how literate noetics alter and work with oral noetics, to examine features of social organization accomplished by printed material, to consider the effects of money on the experience of valuation and on practical commerce, to grapple with how calendars and clocks shape and organize our experience of time and social interaction, and to anticipate the likely side effects of new social media, these are main staples of today's media ecological research.

The overall human environment includes and incorporates technological extensions, and these are never merely add-ons. They alter our sensibilities and capacities, our notions of self and other, our notions of privacy and propriety, and our orientations in space and time. By bringing a systems-view to technological mediation, media ecology both undercuts the "one-thing-at-a-time" rationality fostered by print literacy and also provides a strategic vantage for understanding the kinds of changes currently afoot in the new media landscape.

Conflicts of Interest: The author declares no conflict of interest.

\section{References}

1. Strate, L. Echoes and Reflections: On Media Ecology as a Field of Study; Hampton University Press: Cresskill, NJ, USA, 2006.

2. Strate, L. A Media Ecology Review. Commun. Res. Trends 2005, 23, 1-48.

3. Anton, C. History, Orientations, and Future Directions of Media Ecology. In Communication Uncovered: General Semantics and Media Ecology; Institute of General Semantics: Fort Worth, TX, USA, 2011; pp. 77-91.

4. Meyrowitz, J. No Sense of Place: The Impact of Electronic Media on Social Behavior; Oxford University Press: New York, NY, USA, 1985.

5. Postman, N.; Weingartner, C. Teaching as a Subversive Activity; Delta: New York, NY, USA, 1969.

6. Dewey, J.; Bentley, A.F. Knowing and the Known; Beacon Press: Boston, MA, USA, 1960.

7. McLuhan, M. Understanding Media: Extensions of Man: Critical Edition; Gingko Press: Corte Madera, CA, USA, 2003.

8. Havelock, E.A. The Muse Learns to Write: Reflections on Orality and Literacy from Antiquity to the Present; Yale University Press: New Haven, CN, USA, 1986.

9. McLuhan, M. The Gutenberg Galaxy: The Making of Typographic Man; University of Toronto Press: Toronto, ON, Canada, 1962.

10. Havelock, E.A. Preface to Plato; Harvard University Press: Cambridge, MA, USA, 1963.

11. Goody, J.; Watt, I. The Consequences of Literacy. Compar. Studies in Society and History 1963, 5, 304-345. [CrossRef]

12. Levi Strauss, C. The Savage Mind; University of Chicago Press: Chicago, IL, USA, 1966.

13. Olson, D. The World on Paper: The Conceptual and Cognitive Implications of Writing and Reading; Oxford University: Oxford, UK, 1994.

14. Goody, J. The Interface between the Written and the Oral; Cambridge University Press: Cambridge, MA, USA, 1987.

15. Goody, J. The Domestication of the Savage Mind; Cambridge University Press: Cambridge, MA, USA, 1977.

16. Illich, I.; Sanders, B. The Alphabetization of the Popular Mind; North Point Press: San Francisco, CA, USA, 1988. 
17. Logan, R.K. The Alphabet Effect: The Impact of the Phonetic Alphabet on the Development of Western Civilization; William Morrow and Company, Inc.: New York, NY, USA, 1986.

18. Ong, W.J. Orality and Literacy: The Technologizing of the Word; Methuen: London, UK; New York, NY, USA, 1982.

19. Frazer, J.G. The Golden Bough; Macmillan Company: New York, NY, USA, 1909.

20. Lévy-Bruhl, L. The Notebooks on Primitive Mentality; Harper \& Row Publishers: New York, NY, USA, 1975.

21. Scribner, S.; Cole, M. The Psychology of Literacy; Harvard University Press: Cambridge, MA, USA, 1981.

22. McLuhan, M.; McLuhan, E. Media and Formal Cause; NeoPoiesis Press: Houston, TX, USA, 2011.

23. Anton, C. McLuhan, Formal Cause, and the Future of Technological Mediation. Rev. Commun. 2012, 12, 276-289. [CrossRef]

24. Anton, C.; Logan, R.K.; Strate, L. Taking up McLuhan's Cause: Perspectives on Media and Formal Causality; Intellect Publishing: Bristol, UK, in press.

25. De Kerckhove, D. The Skin of Culture; Somerville House Publishing: Toronto, ON, Canada, 1995.

26. Berger, P.L.; Luckmann, T. The Social Construction of Reality; Doubleday: New York, NY, USA, 1966.

27. Anton, C. Selfhood and Authenticity; SUNY Press: Albany, NY, USA, 2001.

28. Anton, C. Beyond the Constitutive/Representational Dichotomy: The Phenomenological Notion of Intentionality. Commun. Theory 1999, 9, 26-57. [CrossRef]

29. Anton, C. Presence and Interiority: Walter Ong's contributions to a diachronic phenomenology of voice. In Of Ong and Media Ecology: Essays in Communication, Composition, and Literary Studies; Farrell, T.S., Soukup, P., Eds.; Hampton Press: Cresskill, NJ, USA, 2012; pp. 71-90.

30. Anton, C. Diachronic Phenomenology: A Methodological Thread within Media Ecology. Explor. Media Ecol. J. Media Ecol. Assoc. 2014, 13, 3-30. [CrossRef]

(C) 2016 by the author; licensee MDPI, Basel, Switzerland. This article is an open access article distributed under the terms and conditions of the Creative Commons Attribution (CC-BY) license (http://creativecommons.org/licenses/by/4.0/). 